\title{
Calcitonin Precursor
}

National Cancer Institute

\section{Source}

National Cancer Institute. Calcitonin Precursor. NCI Thesaurus. Code C136377.

Calcitonin precursor (141 aa, $\sim 15 \mathrm{kDa}$ ) is encoded by the human CALCA gene. This protein plays a role in calcium flux and bone resorption. 